\title{
FAST FLUX TEST FACILITY (FFTF) MAINTENANCE PROVISIONS
}

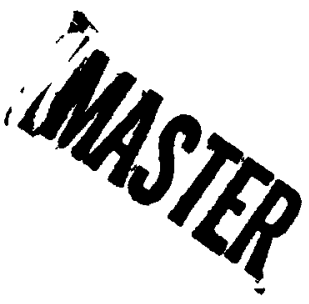

\section{Hanford Engineering Development Laboratory}




\section{DISCLAIMER}

Portions of this document may be illegible in electronic image products. Images are produced from the best available original document. 
Operated by

Westinghouse

Hanford Company

A Subsidiary of

for the U.S. DOE

Westinghouse Electric

Corporation

Contract No.

P.0. Box 1970

DE-AC14-76FF02170

Richland, WA 99352

Hanford Engineering Development Laboratory

INFORMATION CONCERNING USE OF THIS DOCUMENT

NOTICE

This document was prepared as an account of work sponsored by the United States Government. Neither the United States nor the U.S. DOE, nor any of its employes, nor any of its contractors, subcontractors or their employes, makes any warranty, expressed or implied, or assumes any legal liability or responsibility for any third party's use or the results of such use of any information, apparatus, product or process disclosed in this report, or represents that its use by such third party would not infringe privately owned rights.

PRELIMINARY DOCUMENT

This document contains information of a preliminary nature prepared in the course of work under U.S. DOE Contract DE-AC14-76FF02170. This information is subject to corrections or modification upon the collection and evaluation of additional data. 


\section{FAST FLUX TEST FACILITY (FFTF) MAINTENANCE PROVISIONS}

\section{Hanford Engineering Development Laboratory \\ J.L. Marshall May 1981}

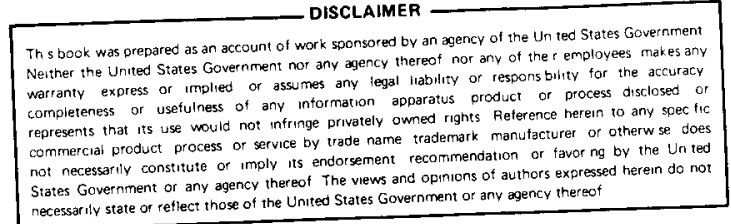

DISTRIBUTIOH OF THIS DOCUMERT IS IIWLIMTED

MGu

HANFORD ENGINEERING DEVELOPMENT LABORATORY

Operated by Westinghouse Hanford Company

P.0. Box 1970 Richland, WA 99352

A Subsidiary of Westinghouse Electric Corporation

Prepared for the U.S. Department of Energy under Contract No. DE-AC1476FF02170 


\title{
FAST FLUX TEST FACILITY (FFTF)
}

MAINTENANCE PROVISIONS

\author{
J. L. Marshall
}

\begin{abstract}
The Fast Flux Test Facility (FFTF) was designed with maintainability as a primary parameter, and facilities and provisions were designed into the plant to accommodate the maintenance function. This paper describes the FFTF and its systems. Special maintenance equipment and facilities for performing maintenance on radioactive components are discussed. Maintenance provisions designed into the plant to enhance maintainability are also described.
\end{abstract}




\section{FAST FLUX TEST FACILITY (FFTF)}

MAINTENANCE PROVISIONS

$$
\text { I. . INTRODUCTION }
$$

The Fast Flux Test Facility (FFTF) is a research reactor designed to test Liquid Metal Fast Breeder Reactor (LMFBR) fuels and materials for the United States LMFBR Program. The FFTF is located at the Hanford Engineering Development Laboratory (HEDL) in Richland, Washington. HEDL is operated by the Westinghouse Hanford Company (WHC), a wholly owned subsidiary of the Westinghouse Electric Corporation, for the Department of Energy (DOE). The FFTF achieved fuil power on December 21, 1980 and is currently in the final phases of the acceptance test program. The FFTF will become fully operational by the end of 1981 with the initiation of the irradiation test program.

The FFTF, while designed to facilitate the maintenance, testing and inspection (MTI) function, is based on existing MTI technology. As a result, the MTI tasks must be performed with special purpose equipment designed for specific tasks.

This paper describes the FFTF and discusses its unique characteristics that affect maintenance and necessitate specialized equipment and procedures. The equipment and facilities provided to support the MTI function are also discussed. 


\section{DESCRIPTION OF THE FFTF}

The FFTF (Figure 1) is a 400-MWt sodium-cooled reactor consisting of 3 completely separate and independant cooling loops. The FFTF, unlike electricity generating facilities, dumps all of its heat into the atmosphere. The FFTF heat transport system (HTS) schematic is shown in Figure 2. The HTS is divided into primary and secondary circuits separated by an Intermediate Heat Exchanger (IHX). This arrangement is necessary because the sodium passing through the reactor becomes radioactive and must be confined within the reactor containment vesse1, necessitating another circuit to transfer the heat ex-containment.

The discussion in this paper will be limited to the radioactive portions of the FFTF, i.e., reactor system and primary HTS, although all sodium systems require specialized equipment and procedures because of the chemical reactivity of sodium with air and water.

\section{A. FFTF COOLANT CHARACTERISTICS}

The sodium coolant in the FFTF has several characteristics that affect maintenance operations related to the reactor and primary cooling system.

Sodium becomes radioactive in the form of isotopes ${ }^{22} \mathrm{Na}$ and ${ }^{24} \mathrm{Na} .{ }^{24} \mathrm{Na}$ has a half-life of 15 hours and decays to acceptable "hands on" levels in two weeks. ${ }^{22} \mathrm{Na}$ has a half-life of 2.6 years and results in some residual activity necessitating the draining of the primary HTS piping, if 1 ong and extensive maintenance operations are planned adjacent to or on components in the system.

The sodium also results in the mass transport of the radioactive isotopes ${ }^{54} \mathrm{Mn},{ }^{58} \mathrm{Co}$ and ${ }^{60} \mathrm{Co}$ from the hot reactor core components $\left(1000^{\circ} \mathrm{F}\right)$ to the colder regions of the primary circuit where they plate out on the coolant boundary, resulting in radioactive piping and components. The distribution of this plateout is shown in Figure 3 . In addition, sodium freezes at 
$208^{\circ} \mathrm{F}$ imposing certain design and operating constraints on the plant that affect maintenance of sodium systems and components.

As mentioned earlier, sodium is also highly reactive with air and water necessitating special equipment and procedures when breaching a sodiumcontaining boundary or handling sodium-wetted components.

\section{R. FFTF RADIOACTIVE MAINTENANCE PHILOSOPHY}

Spare components are provided for those items that have a high risk of failure. In the event of such failures, the component is removed and replaced with a spare unit, and the failed component is stored until repair and refurbishment can be accomplished. In the case of small radioactive valves, no attempt is made to repair them, and they are disposed of as waste.

Unscheduled maintenance of a number of components can be expected to occur. However, because of the large number of components, the number of potential failures is quite large, although the probability in a majority of the cases is low. When considering radioactive components or components in a radioactive environment, large amounts of money could be invested on special purpose equipment based on contingencies (some of which may never occur). Obviously, this is impractical. The FFTF Project attempted to classify potential failures based on the degree of risk. This was done by means of the risk assessment grid shown in Figure 4. The following factors were used in determining the impact-of-failure rating:

- $\quad$ HIGH

-- Operation cannot be performed safely without special equipment and procedures

-- Design, fabrication and testing of equipment requires a long lead time (>6 months)

-- On-site fabrication of equipment at time of need is not practical because of complexity 
- MODERATE

-- Operation cannot be performed without special equipment and procedures

-- Design, fabrication and testing of equipment requires a moderate lead time ( $<6$ months)

-- On-site fabrication of less sophisticated equipment can be provided at the time of need and utilized safely with decreased efficiency (more people required and longer plant downtime)

- LOW

-- Operation can be performed with proper precautions and minimum equipment fabrication at the time of need

-- Design and fabrication requires a short lead time ( $<1$ week)

With this approach, an attempt was made to judiciously provide the equipment that would have the most severe impact if it were not available in the event of a component failure. Even this approach requires a large expenditure of funds for equipment that will have very limited use. 


\section{FFTF MAINTENANCE}

\section{A. MAINTENANCE OF LARGE RADIOACTIVE COMPONENTS}

The FFTF is equipped with a hot cell inside the containment called the Inter im Examination and Maintenance (IEM) Ce11. (See Figures 5, 6 and 7.) The IEM Cell has a two fold purpose: 1) remote disassembly and inspection of fue 1 and materials test assemblies and 2) maintenance of reactor components, such as the Instrument Tree (IT), In-Vessel Fuel Handling Mach ine (IVHM) (Figure 8), the Primary Sodium Pump (PSP) and the IHX tube bundle.

The IEM Cell is equipped with electro-mechanical manipulators (150-1b and 30-1b capacity), masterslave manipulators (25-1b and 50-1b capacity), remotely operated 5-ton and 10-ton capacity cranes, and a myriad of special tools and equipment. In order to perform maintenance on the above-mentioned components, special fixtures must be installed in the IEM Cell on the maintenance turntable. These fixtures and the accessory equipment are designed to be installed and remotely operated using the IEM Cell equipment. These fixtures have special features, such as elevating devices, translating material handling tables, tooling plates, force effection for pressing operations, etc.

An example of a maintenance operation in the IEM Cell is the replacement of the foot assembiy on the IVHM. The IVHM is removed from the reactor, using the Segmented Maintenance Cask (SMC) (Figure 9), replaced with the spare unit and the reactor put back into operation. After the IVHM is removed, it is stored in an inerted shielded vesse 1 in the Maintenance and Storage Facility (MASF) (Figure 10) until the IEM Cell can be made ready for the maintenance operation. Once the IEM Cell is ready, the IVHM disassembly stand is installed in the cell. The IVHM is then brought into containment using the SMC and lowered into the disassembly stand (Figure 11). While suspended from the cask, the rigid arm structure is separated from the rotating plug and secured in the disassembly stand using the pedestalmounted manipulator and the appropriate tools. The rotating plug is then 
pulled back up into the cask and transported back to the MASF for storage. Figure 12 shows the use of the pedestal-mounted manipulator with an impact wrench to remove a bolt that secures the foot assembly to the rigid arm. Once the repairs are made, the rotating plug is brought back, and the IVHM is reassembled and transported back to the MASF where it will be stored as the spare unit in an inerted shielded vessel.

In addition to inerted and shielded storage, the MASF provides a sodium cleaning capability. However, radioactive maintenance in the IEM Cell will not require sodium removal from the components since the operations are in an inerted environment. However, if a secondary sodium system pump must be repaired, this would be a hands-on operation in air and would require the removal of the sodium.

As mentioned earlier, the primary HTS components become radioactive due to corrosion product plateout. Research is currently in progress to develop a decontamination process that will remove the radioactive isotopes. Once developed, this system will be incorporated into the MASF. Once incorporated, failed primary HTS components will be cleaned and decontaminated permitting hands-on maintenance in the MASF. Reactor components must still be maintained in the IEM Cell.

\section{B. MAINTENANCE OF PRIMARY HTS COMPONENTS IN THE HTS VAULTS}

Figures 13 and 14 show the layout of the HTS vaults. A number of valves, vapor traps, freeze vents, pressure sensors, thermocouples, etc. that have a potential for failure are located in these vaults. The corrosion product plateout results in radiation levels in the vault anywhere from $120 \mathrm{mR} / \mathrm{h}-$ gamma to $700 \mathrm{mR} / \mathrm{h}$-gamma, depending on the location and component.

Early in the design of FFTF maintenance, access openings were established in the HTS vault ceiling, and maintenance easements were established with in the vaults to permit access to components. The cell ceiling structure dictated the size and location of the access openings to a large degree but, as can 
be seen, large openings were provided in the most crucial areas above the large components. The small auxiliary piping was designed around these openings and every attempt was made to locate the auxiliary system components and instrumentation adjacent to these openings.

In anticipation of future development of special maintenance equipment, threaded inserts with a holding capacity of 10 tons were imbedded in a grid pattern on 4-ft centers in the ceiling and 6-ft centers in the walls.

The design of the maintenance equipment in the vaults has not been started at this date. However, some developmental work has been completed on pipe welders and cutters that could be adapted to remote installation and operation. (See Figure 15, 16, 17, 18.) 


\section{INSPECTION}

\section{A. IN-SERVICE INSPECTION EQUIPMENT}

A remotely operated closed-circuit television (TV) system was developed for remote inspection of the reactor vessel and nozzle welds. (See Figures 19 and 20.) This system consists of two TV delivery transporters: 1) a trolley device for inspection of the reactor vessel support weld and 2) a wheeled transporter that operates in the annulus formed by the reactor vessel and guard vessel.

Also under development at HEDL is an ultrasonic scanning system for inspection of stainless steel piping welds (Figures 21 and 22). Future developmental plans for this system include a remote inspection capability. 


\section{SUMMARY}

As can be seen, the FFTF was designed with maintenance in mind and considerable effort and capital has been invested in maintenance facilities and equipment. However, there are areas where robotic technology would greatly reduce radiation exposure of personnel, particularly in the HTS vaults. 


\section{ACKNOWLEDGMENTS}

The author wishes to acknowledge the efforts of Messrs. J. P. McBride and

H. C. Stahl, who provided assistance in compiling the information in this paper. 


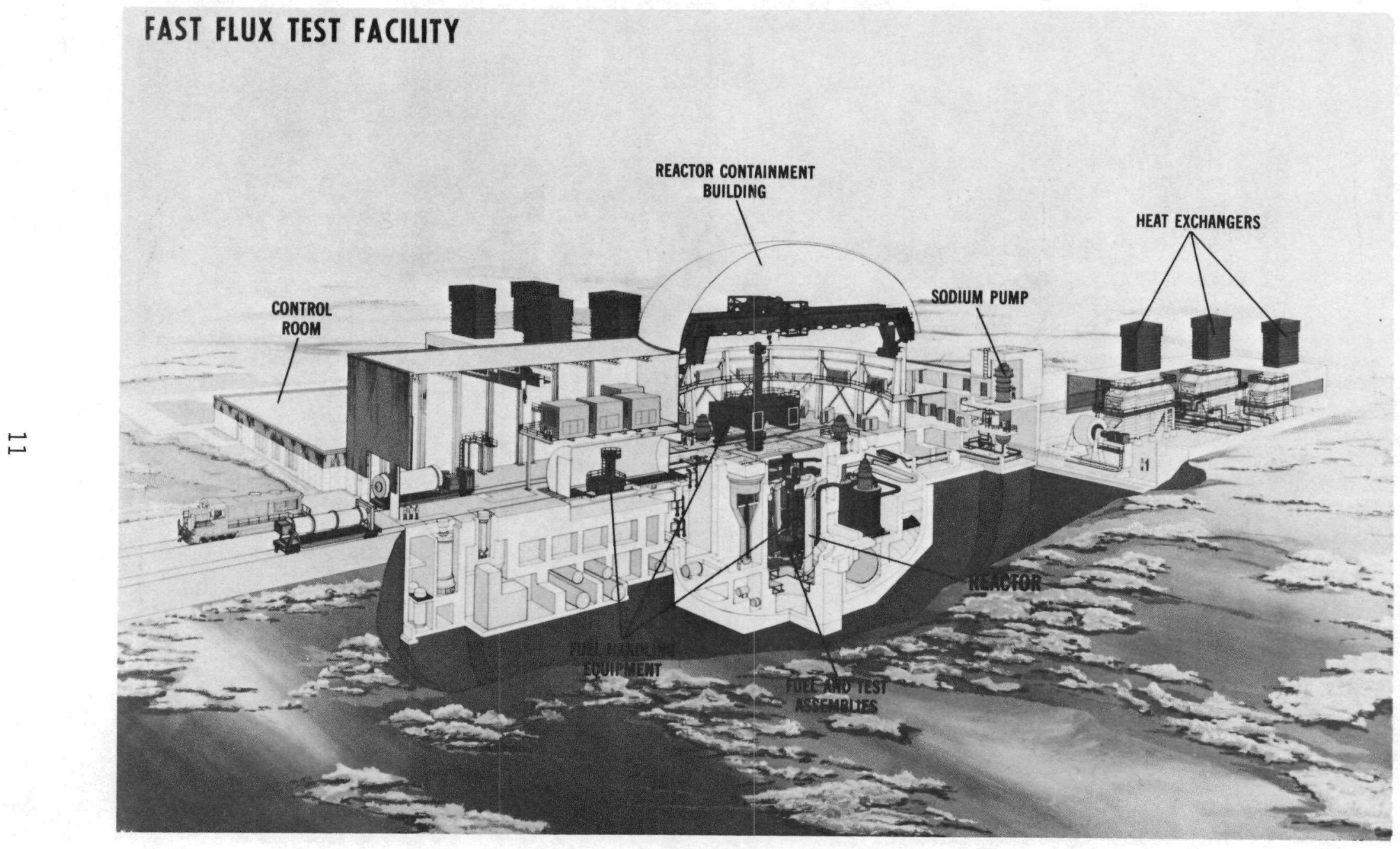

FIGURE 1. Fast Flux Test Facility. Neg 8101694-1 


\section{FFTF SODIUM COOLANT SYSTEM}

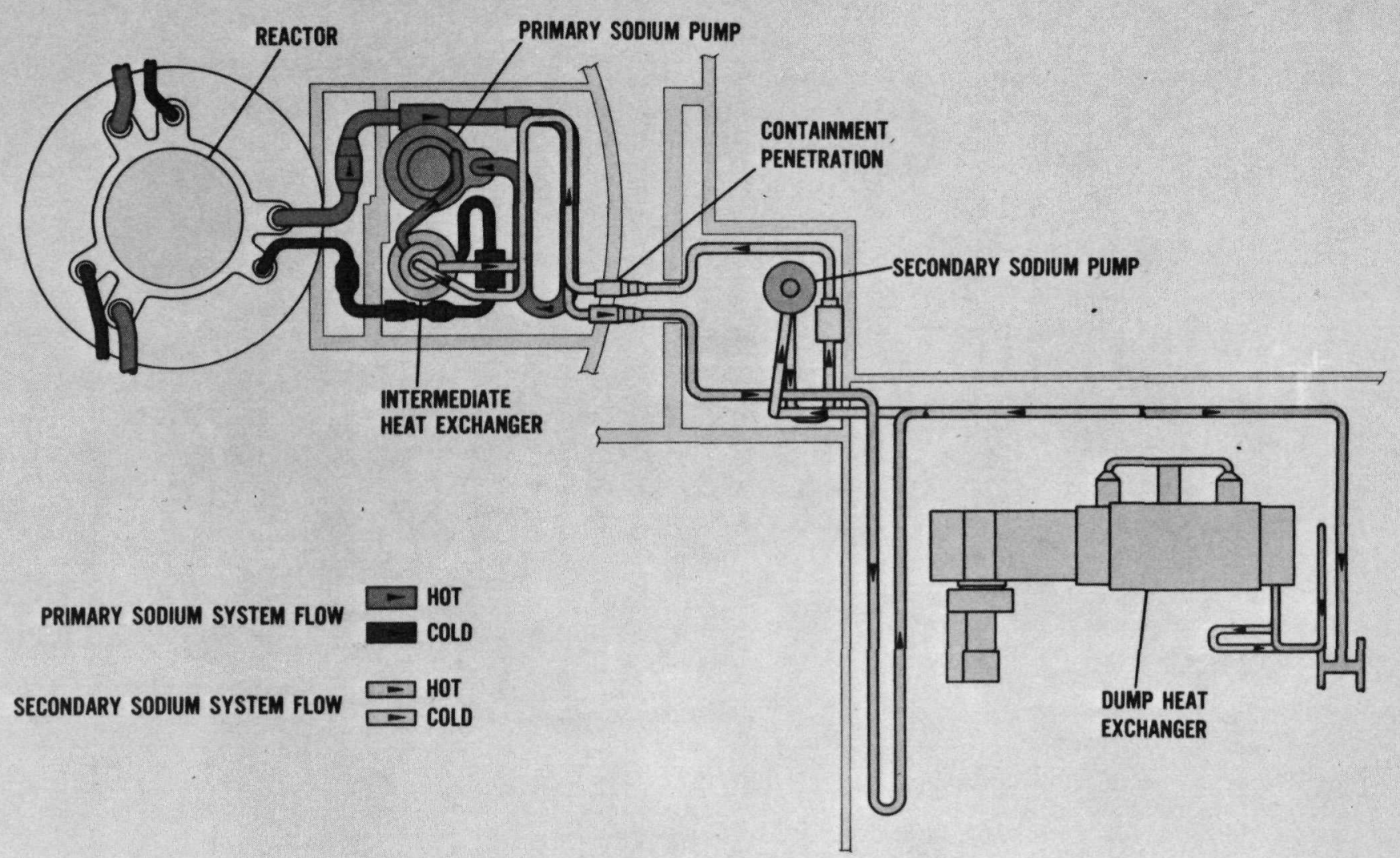

FIGURE 2. FFTF Sodium Coolant System Schematic. Neg 747342-1cn 


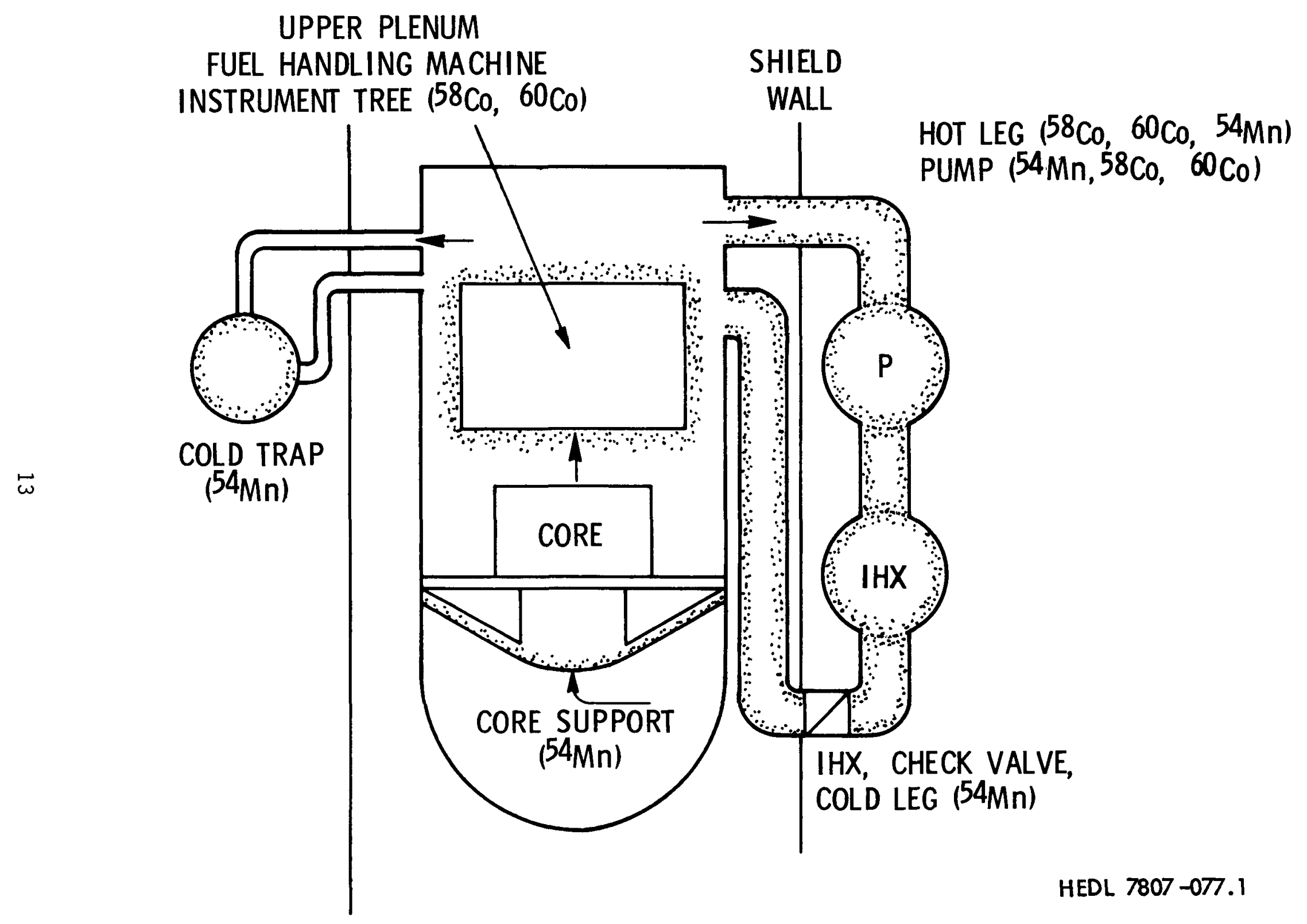

FIGURE 3. Uncontrolled Deposition Locations in FFTF. Neg 7807683-1 
IMPACT OF FAILURE ON PLANT OPERATIONS AND PERSONNEL SAFETY IF EQUIPMENT NOT AVAILABLE

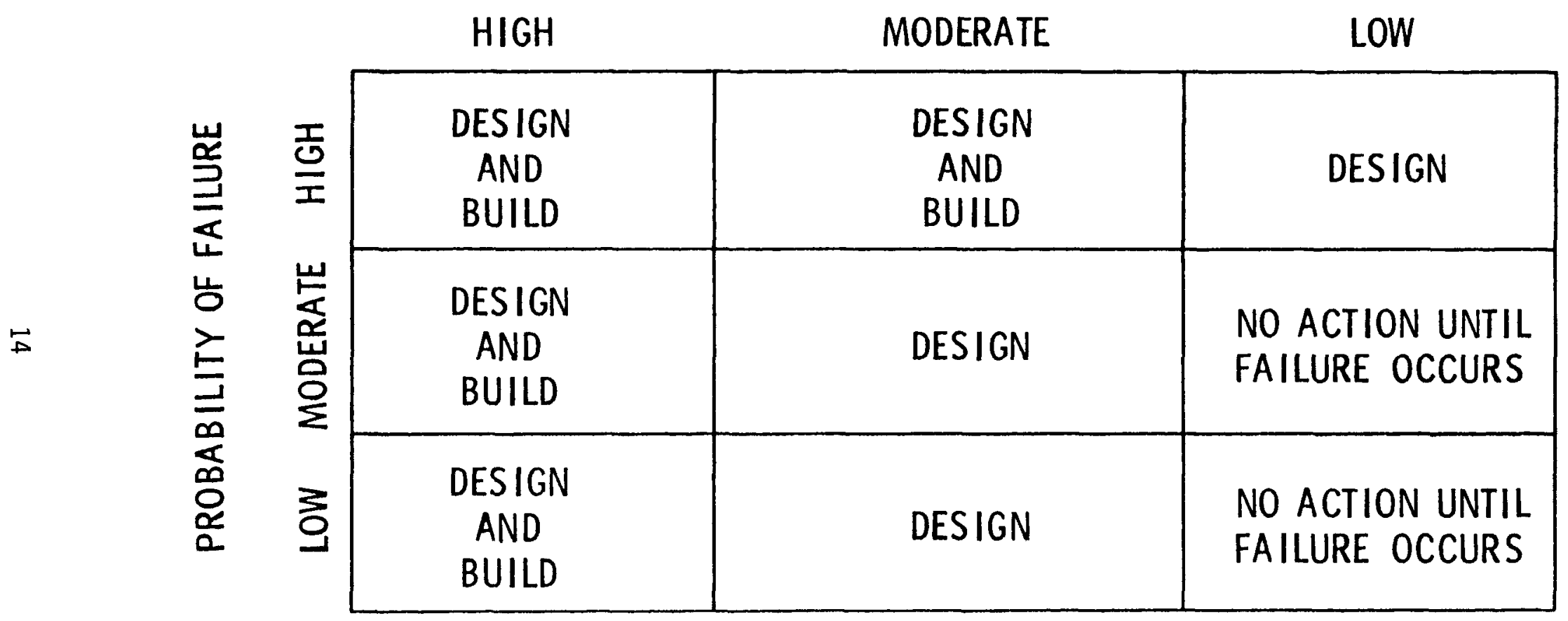

HEDL 7806-244.1

FIGURE 4. Risk Assessment Grid Used to Determine Equipment Needs and Priority. 


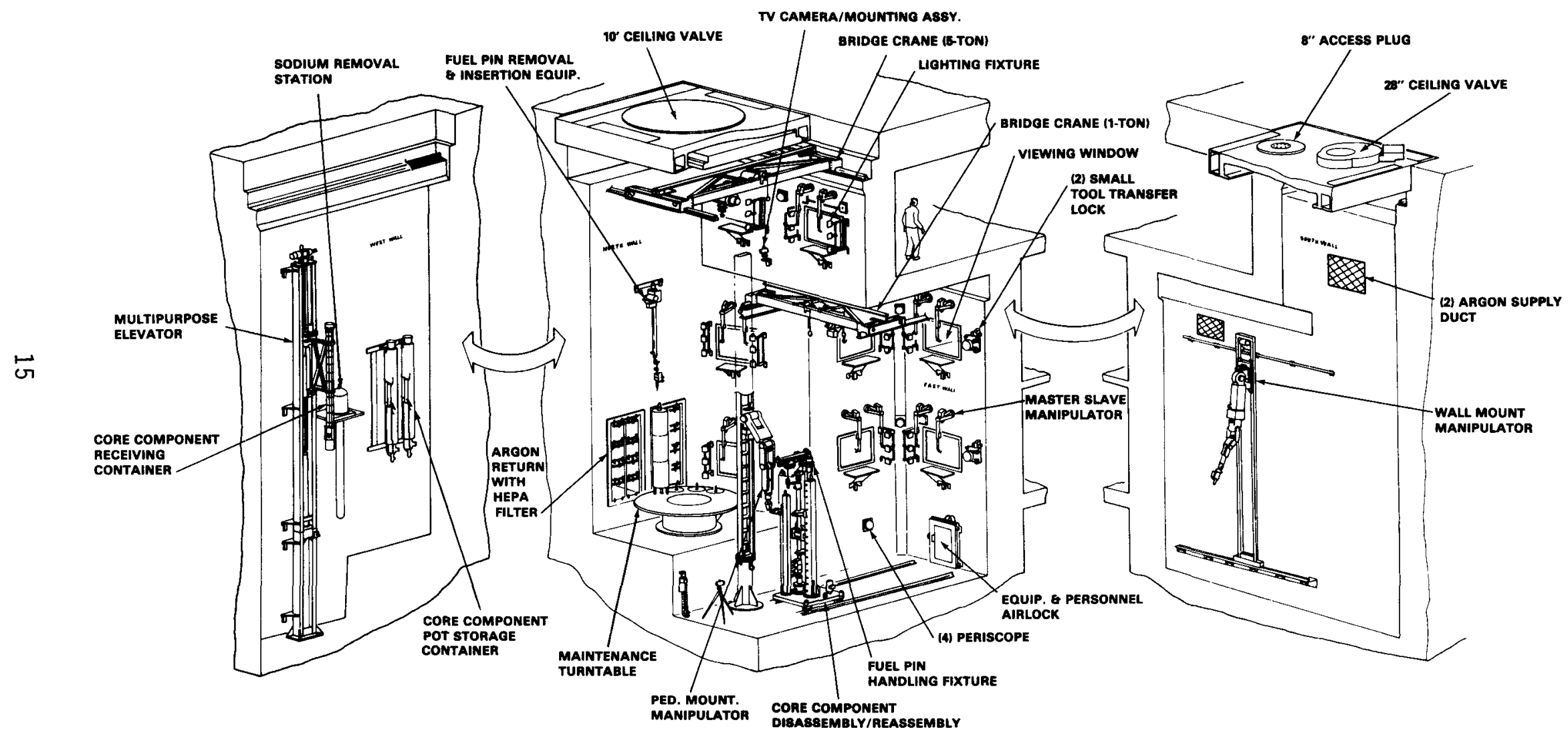

MEDL \$012-12.1

FIGURE 5. Interim Examination and Maintenance (IEM) Cell Schematic. Neg 8100403-1 


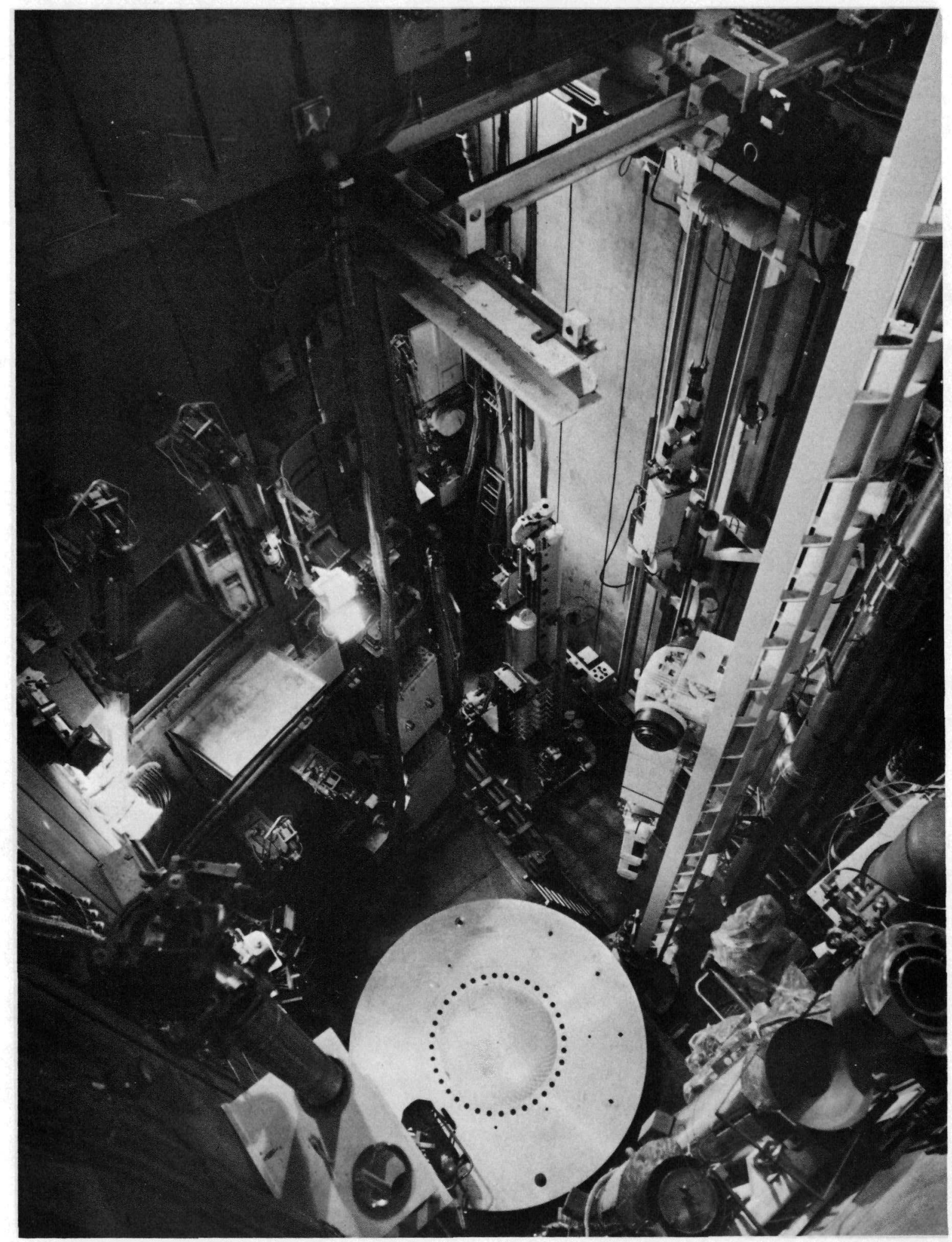

FIGURE 6. IEM Cel1. Neg 7910537-8cn 


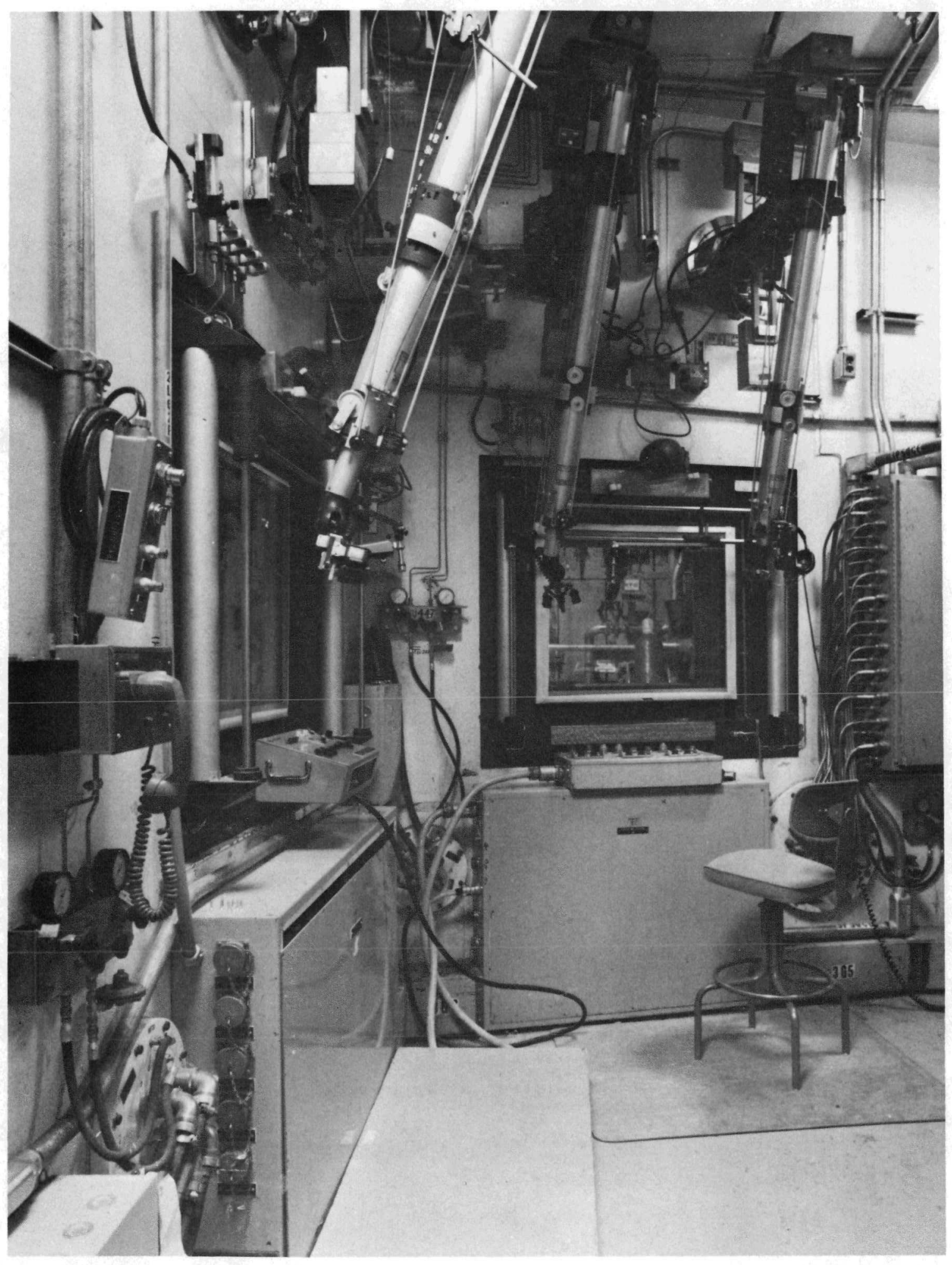

FIGURE 7. IEM Cel1 Operator Station. Neg 7910537-36cn 


\section{FFTF REACTOR}

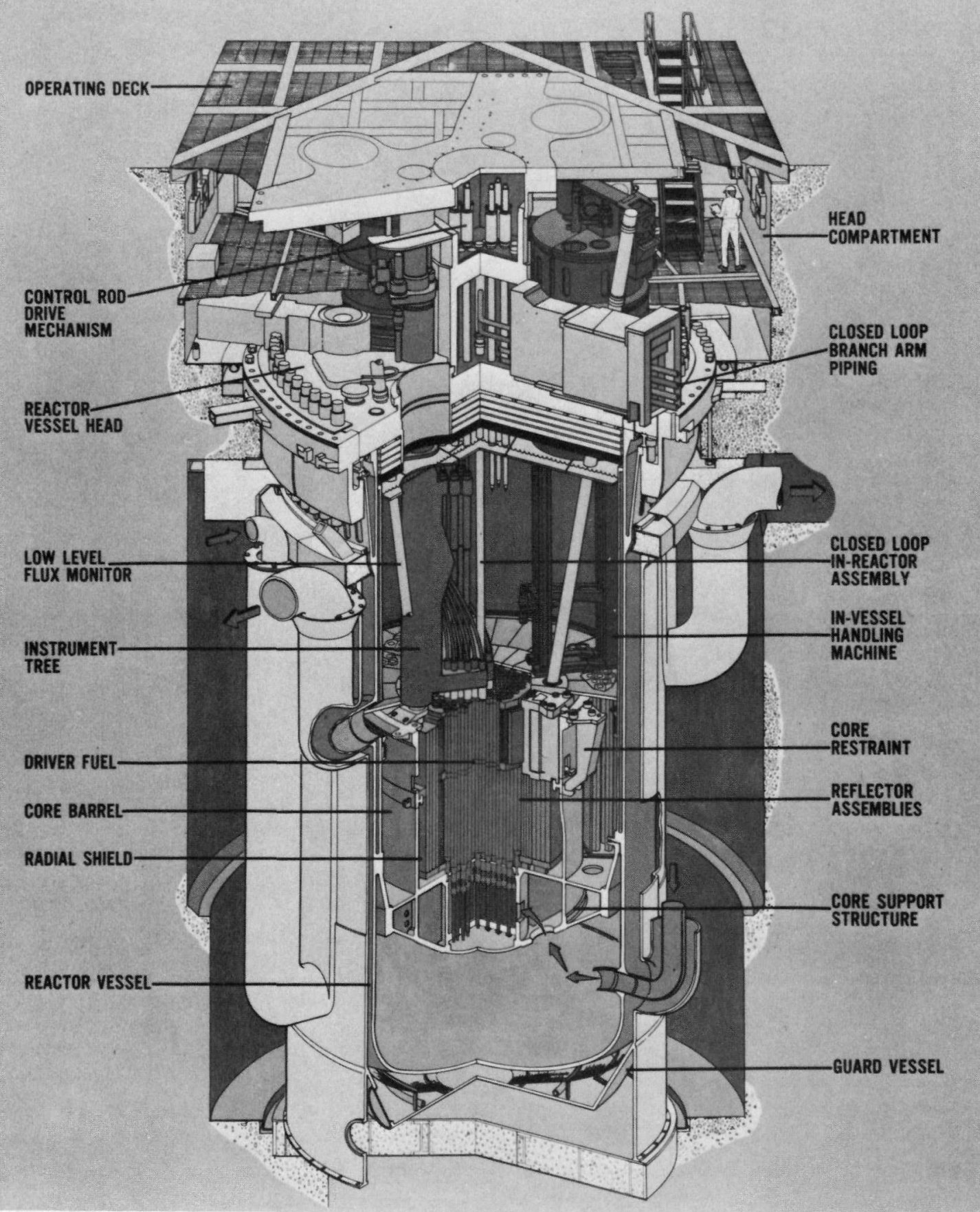

FIGURE 8. In-Vessel Fuel Handling Machine (IVHM). Neg 76194-2cn 


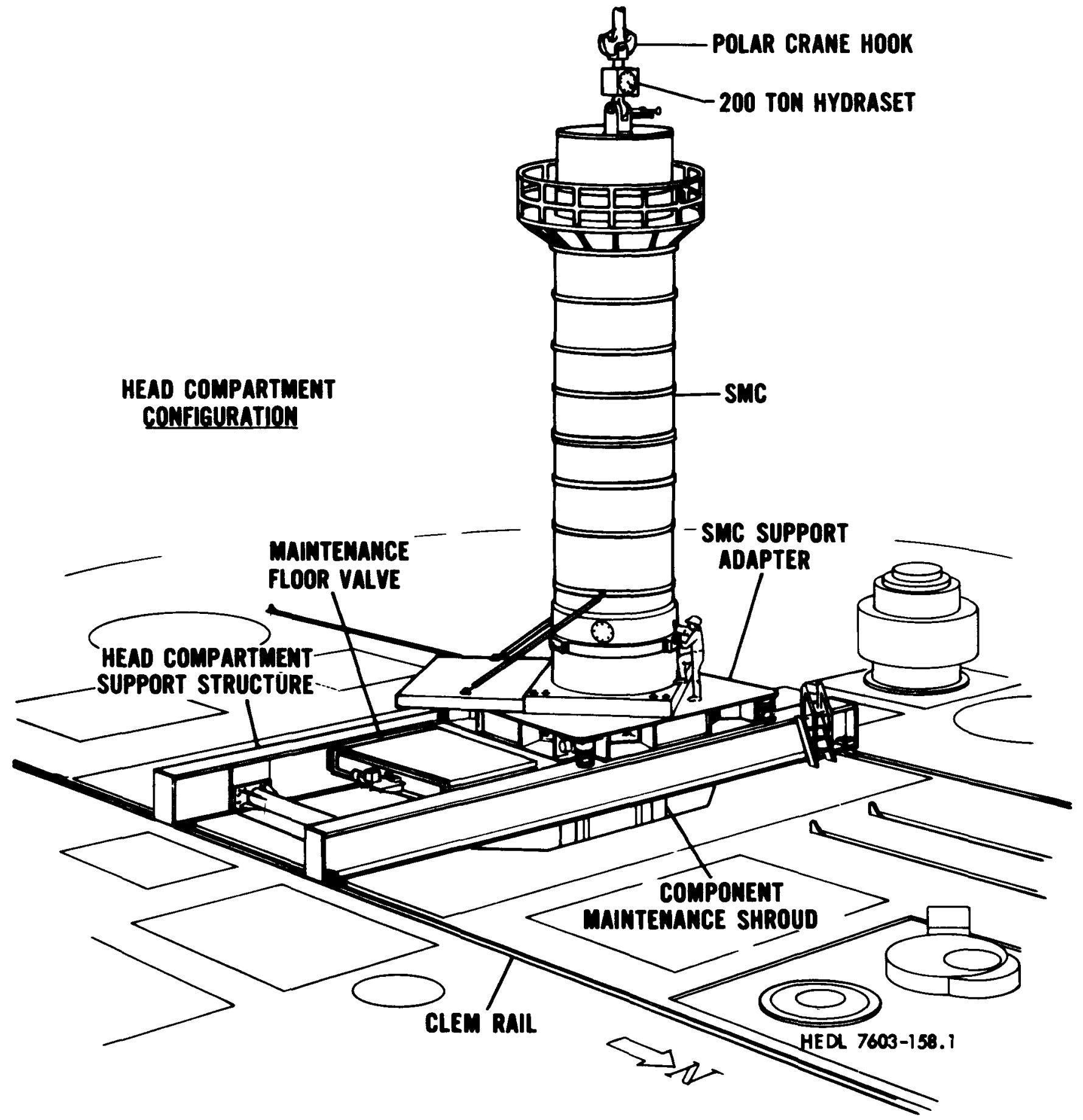

FIGURE 9. Segmented Maintenance Cask (SMC). Neg 7807228-1 


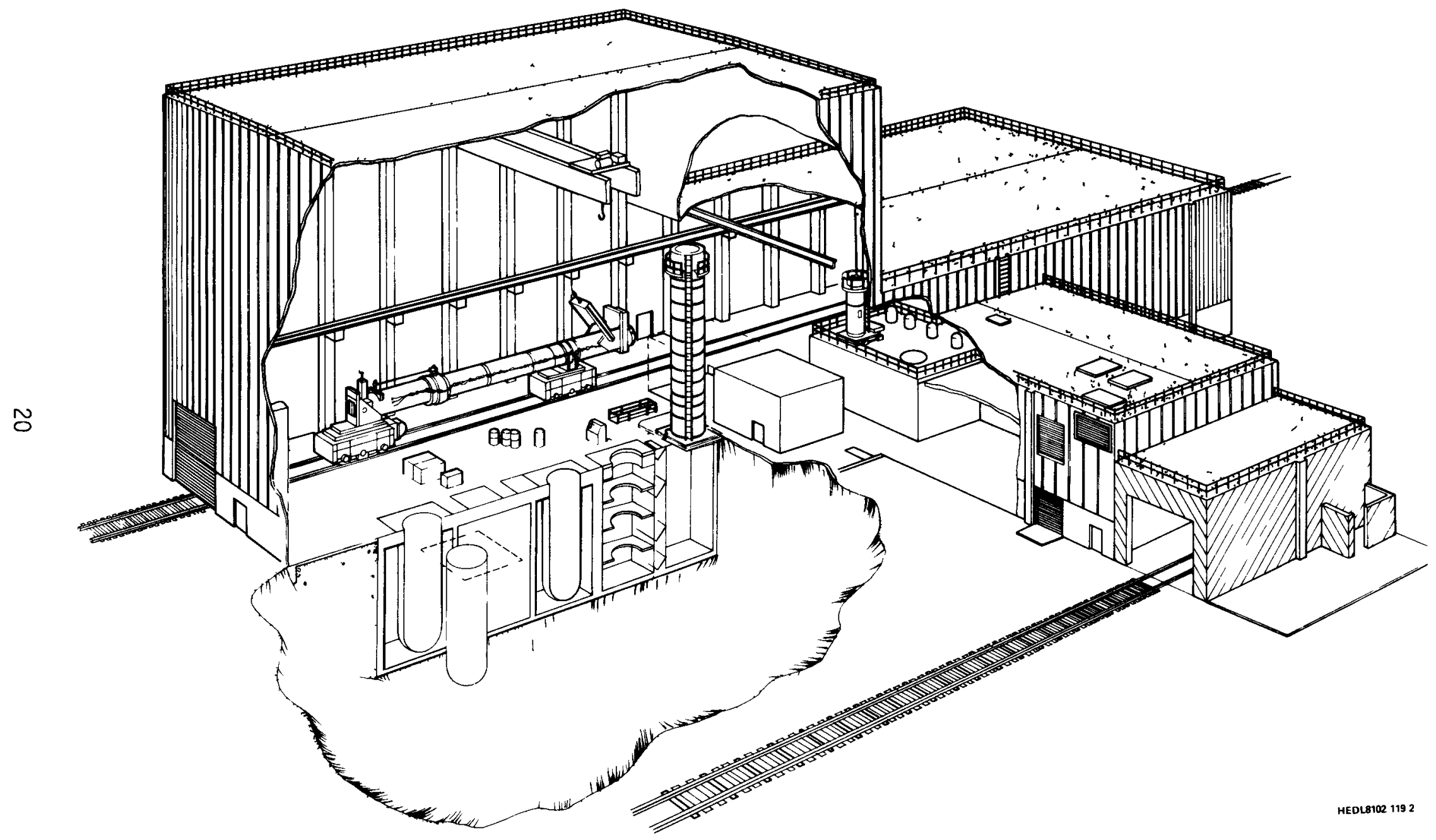

FIGURE 10. Maintenance and Storage Facility (MASF). Neg 8101402-2 


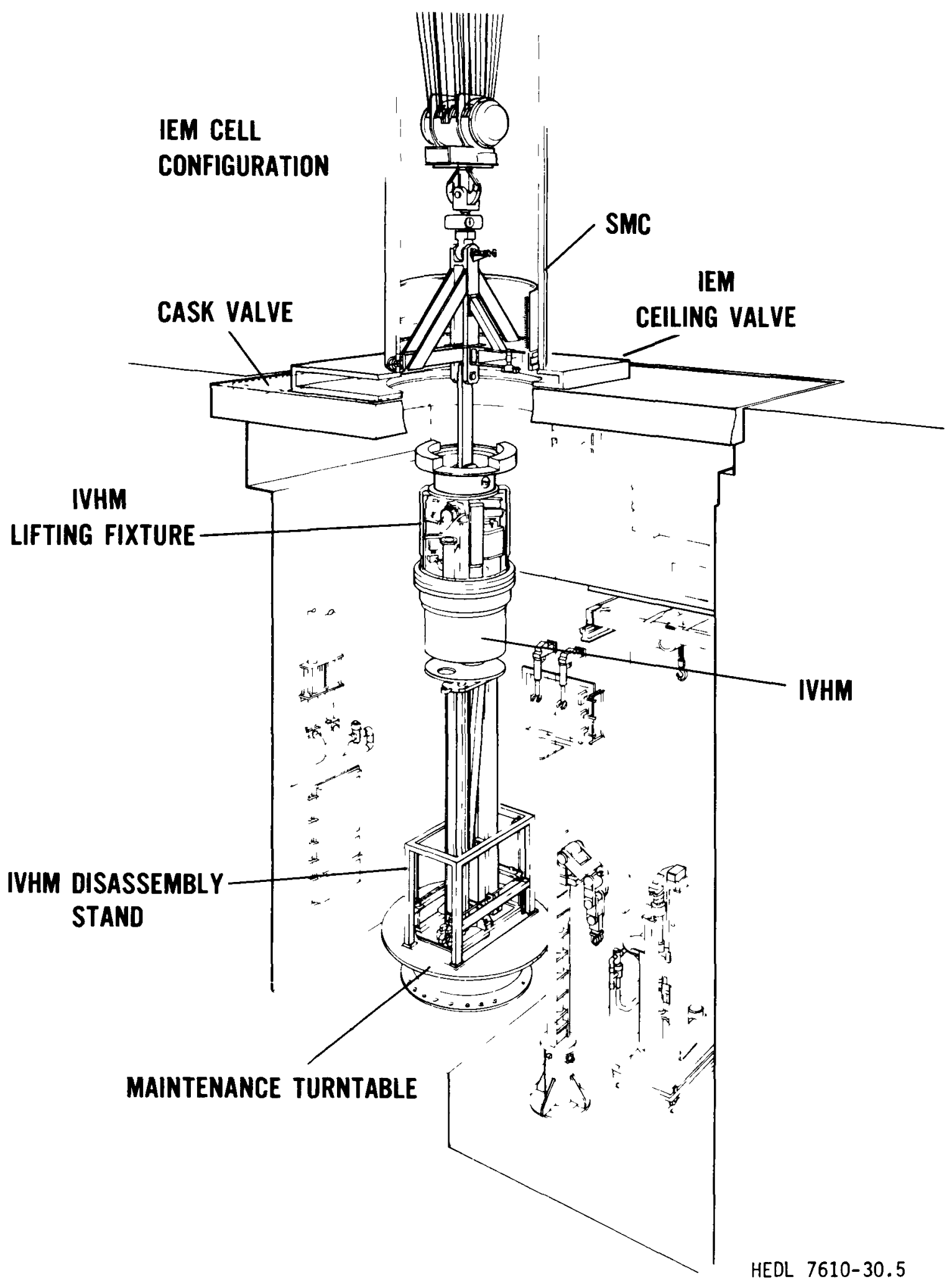

FIGURE 11. Segmented Maintenance Cask (SMC) in IVHM Disassembly Stand. Neg 7807228-2 


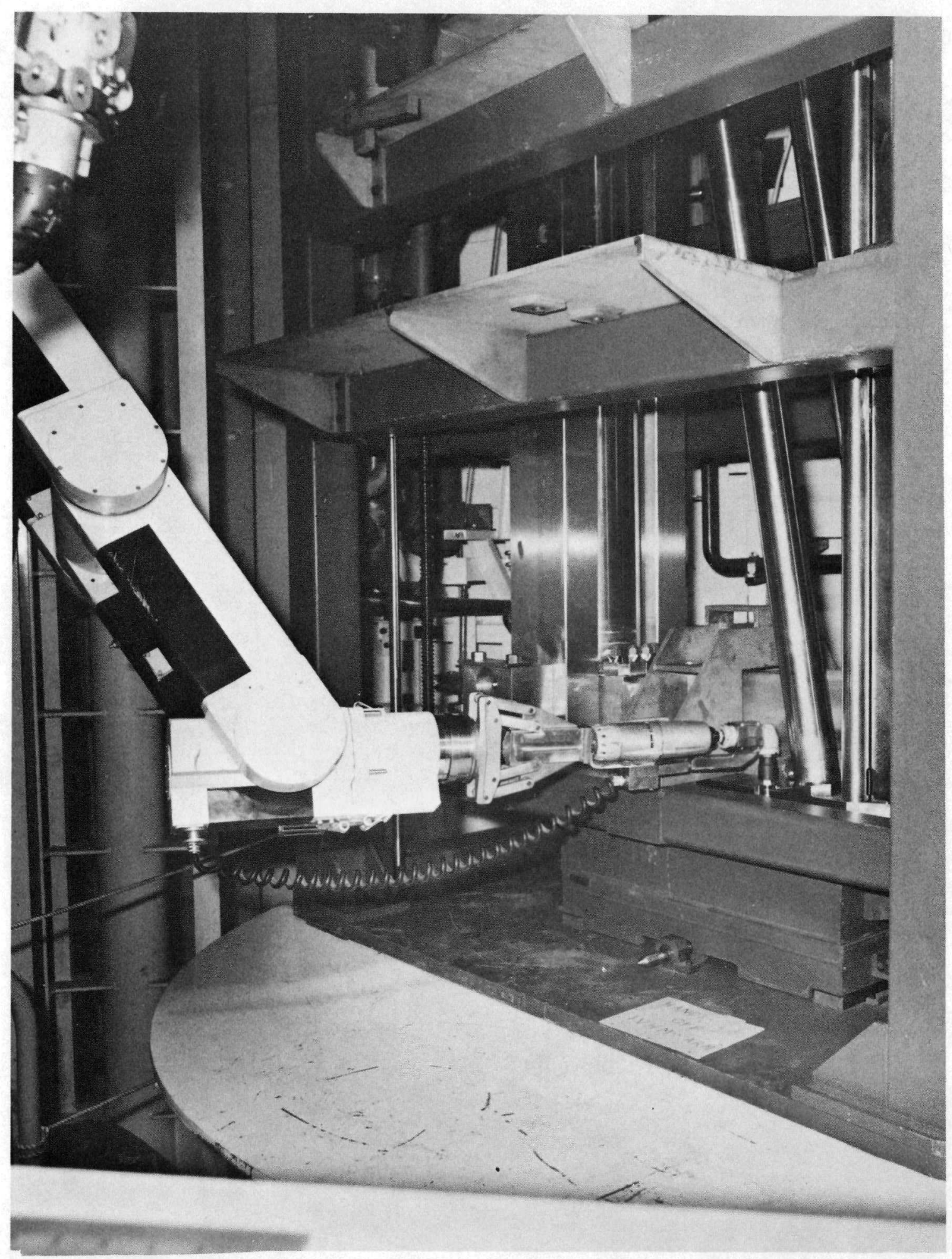

FIGURE 12. IEM Ce11 Remote Maintenance Operation on IVHM. Neg 771124-184cn 


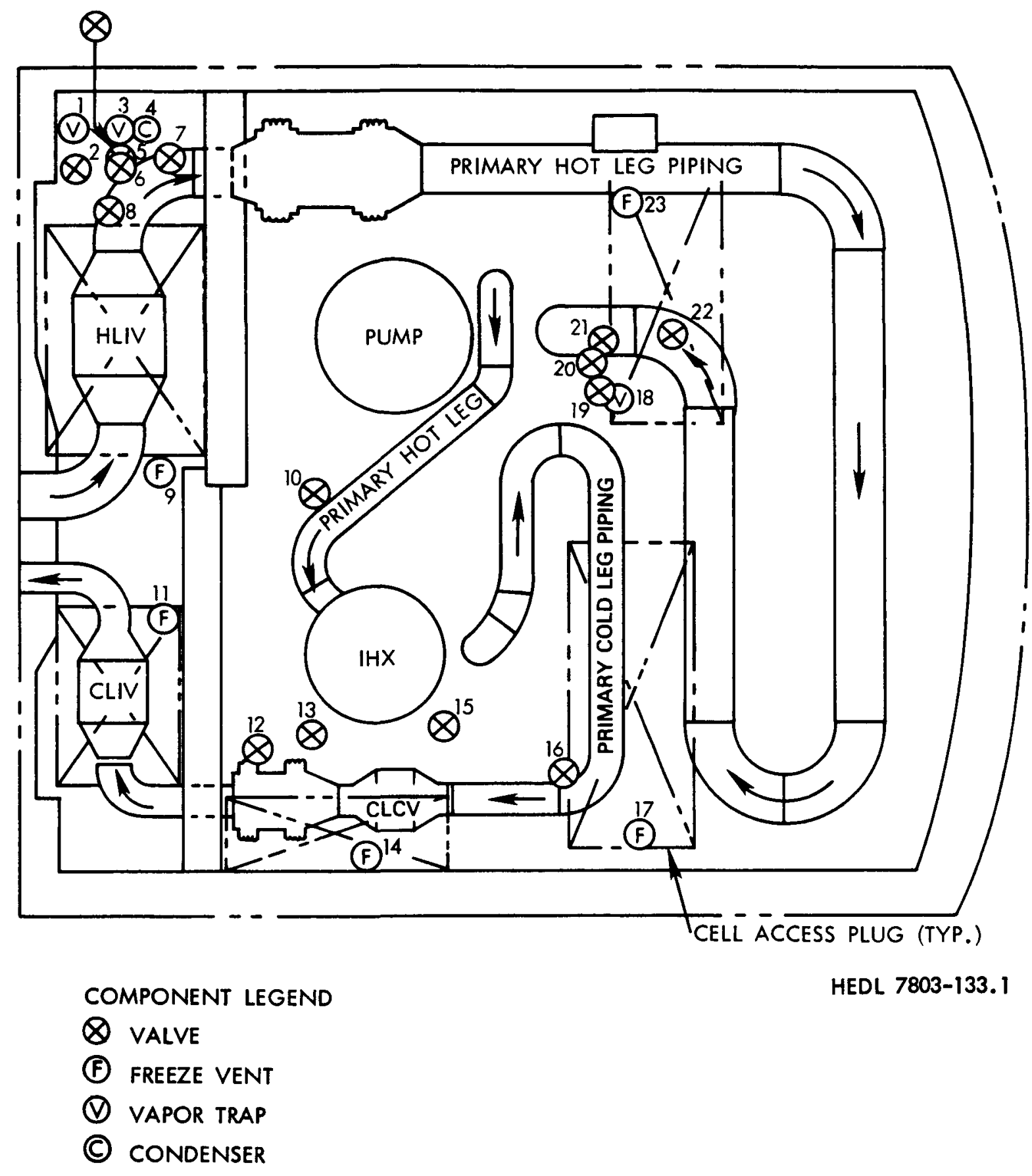

FIGURE 13. General Arrangement of HTS Cell Small Components. 


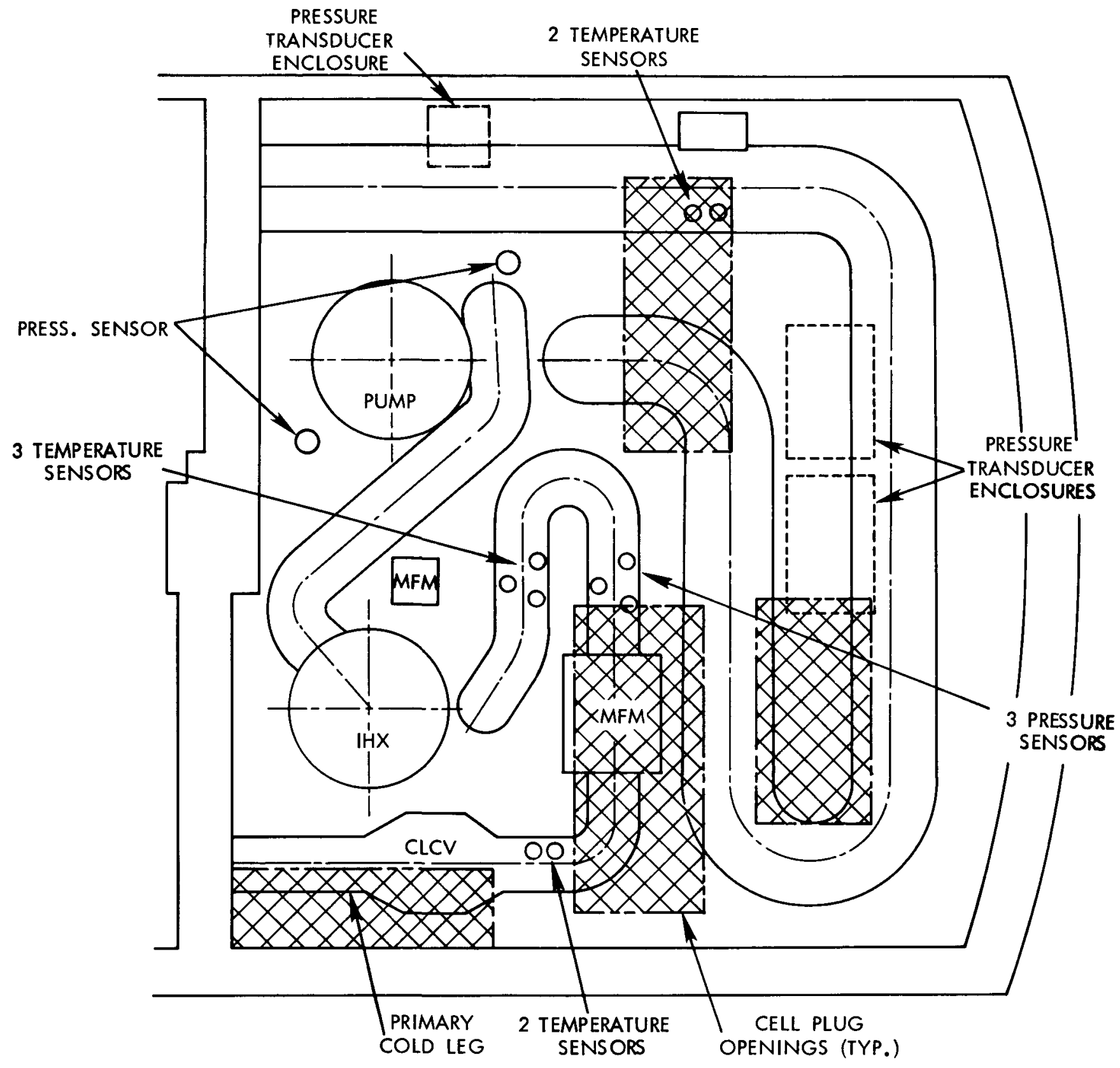

HEDL 7803-133.2

FIGURE 14. General Arrangement of HTS Cell Instrumentation. Neg 8101464-1 


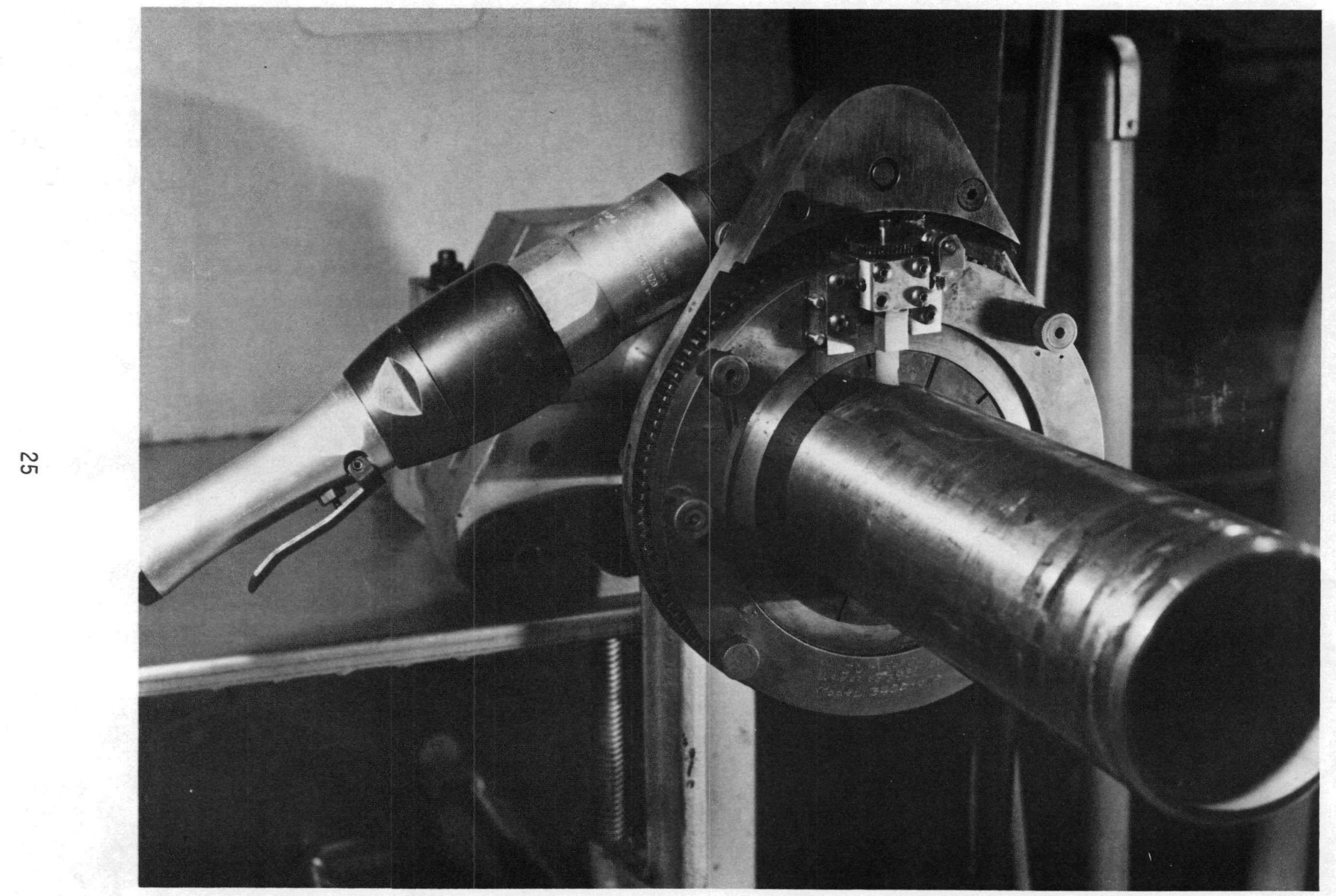

FIGURE 15. Small Diameter Pipe Cutter. Neg 7610406-4cn 


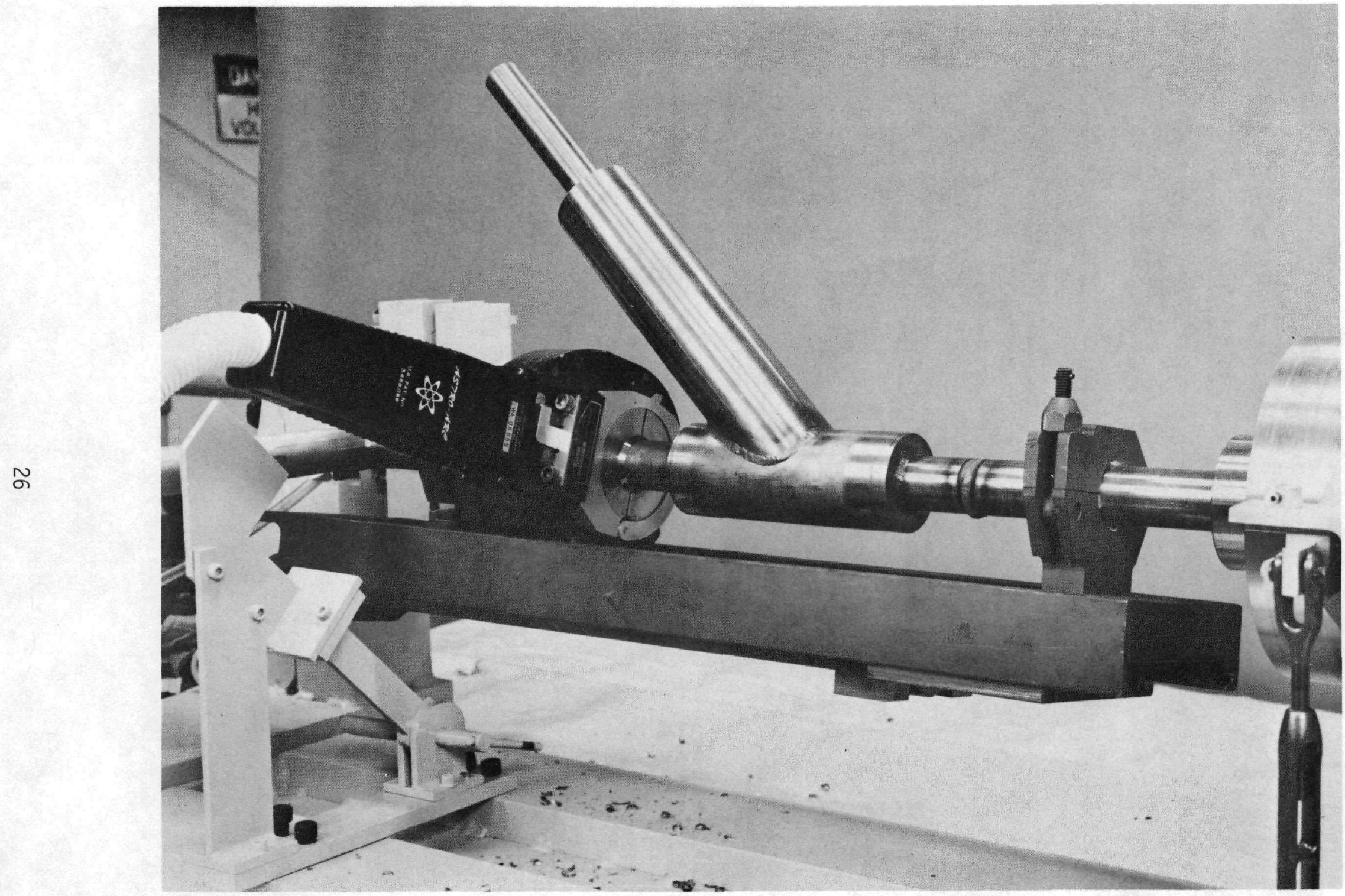

FIGURE 16. Small Diameter Pipe Welder. Neg 779799-24cn 


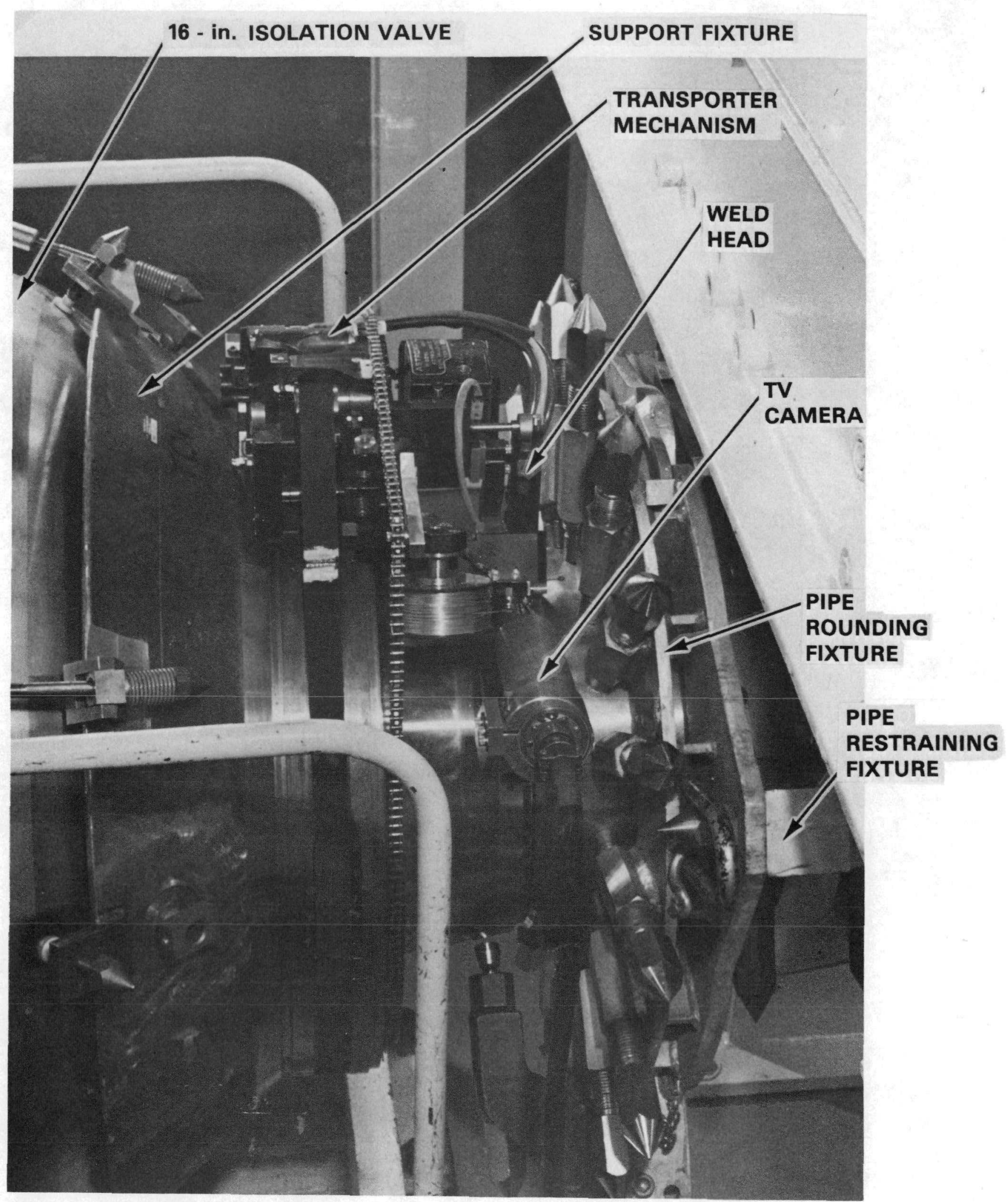

FIGURE 17. 16-In. Automatic Pipe Welder. Neg 776115-4cn

HEDL 8105-001.3 


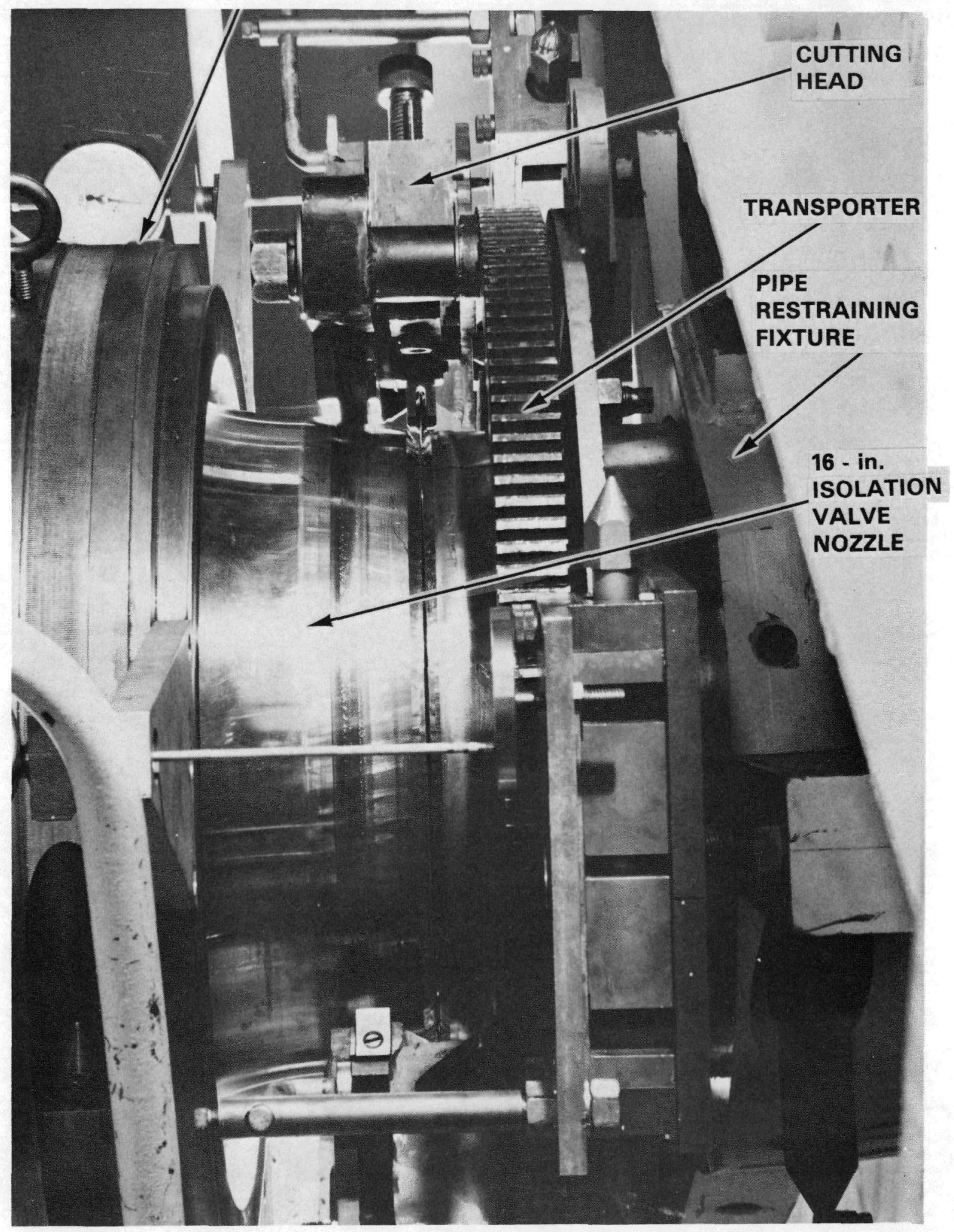

FIGURE 18. 16-In. Automatic Pipe Cutter. Neg 775147-2cn 


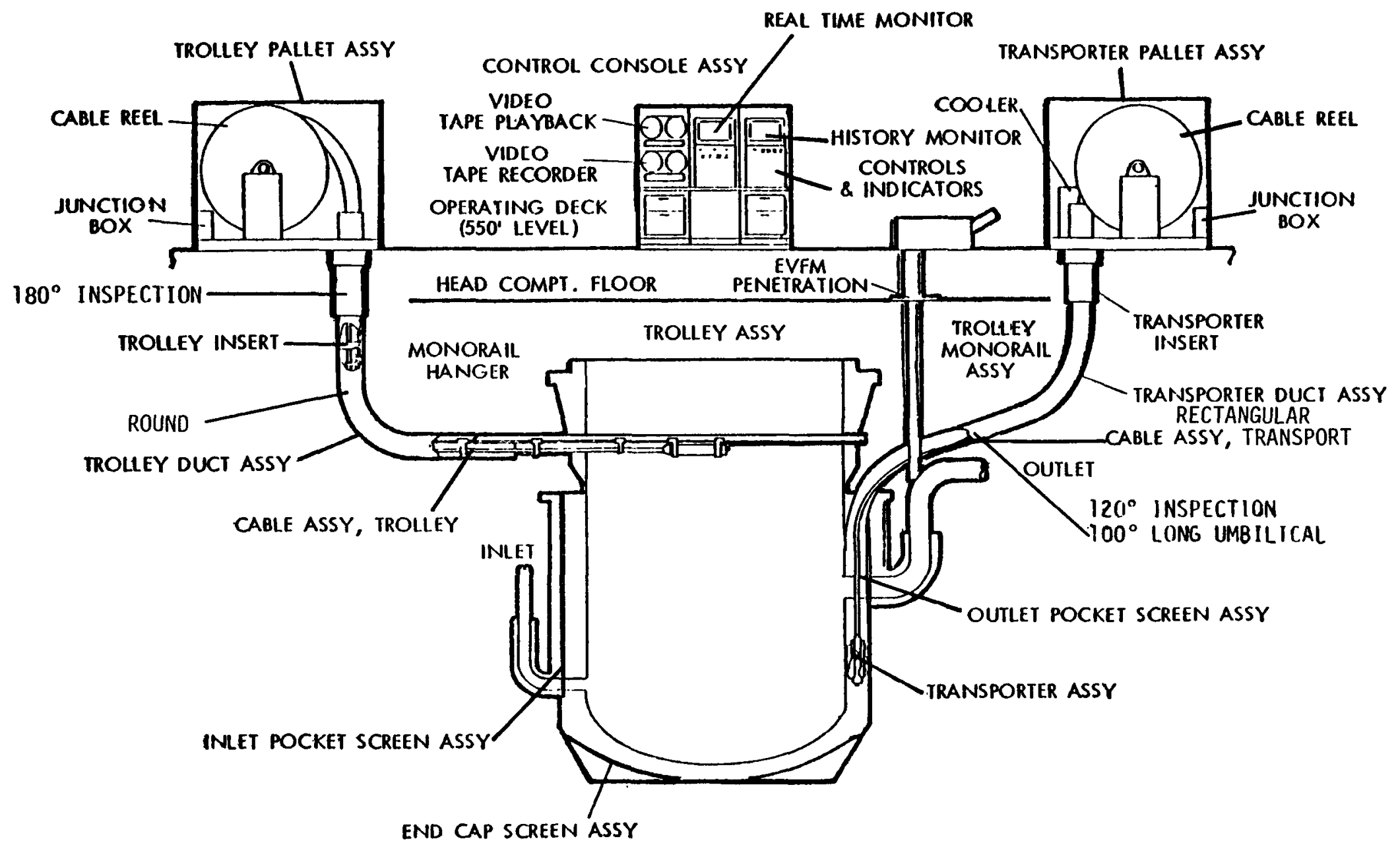

FIGURE 19. Surveillance and In-Service Inspection (SISI) System Diagram. 


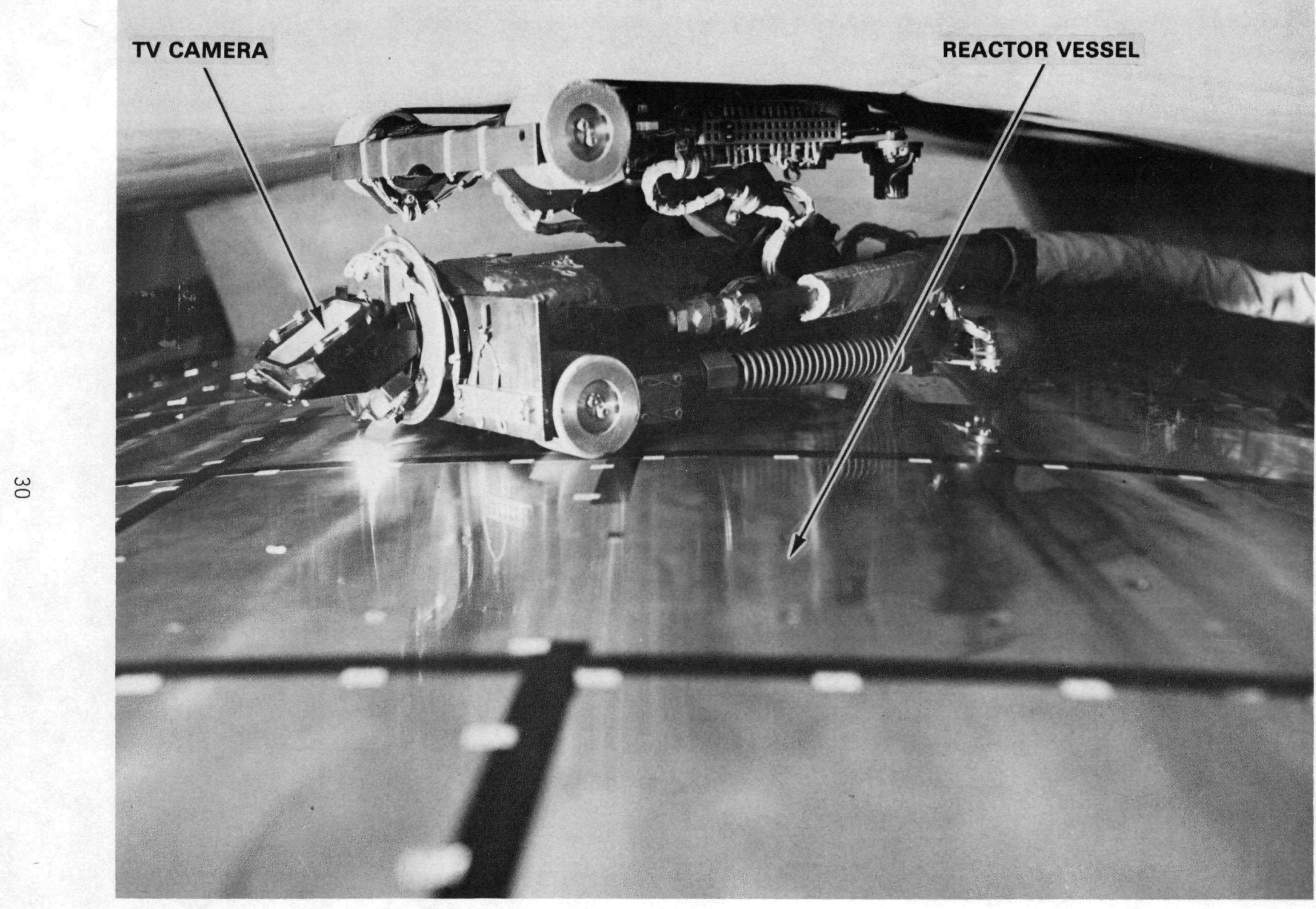

FIGURE 20. TV Transporter. Neg 7710149-2

HEDL 8105-001.4 


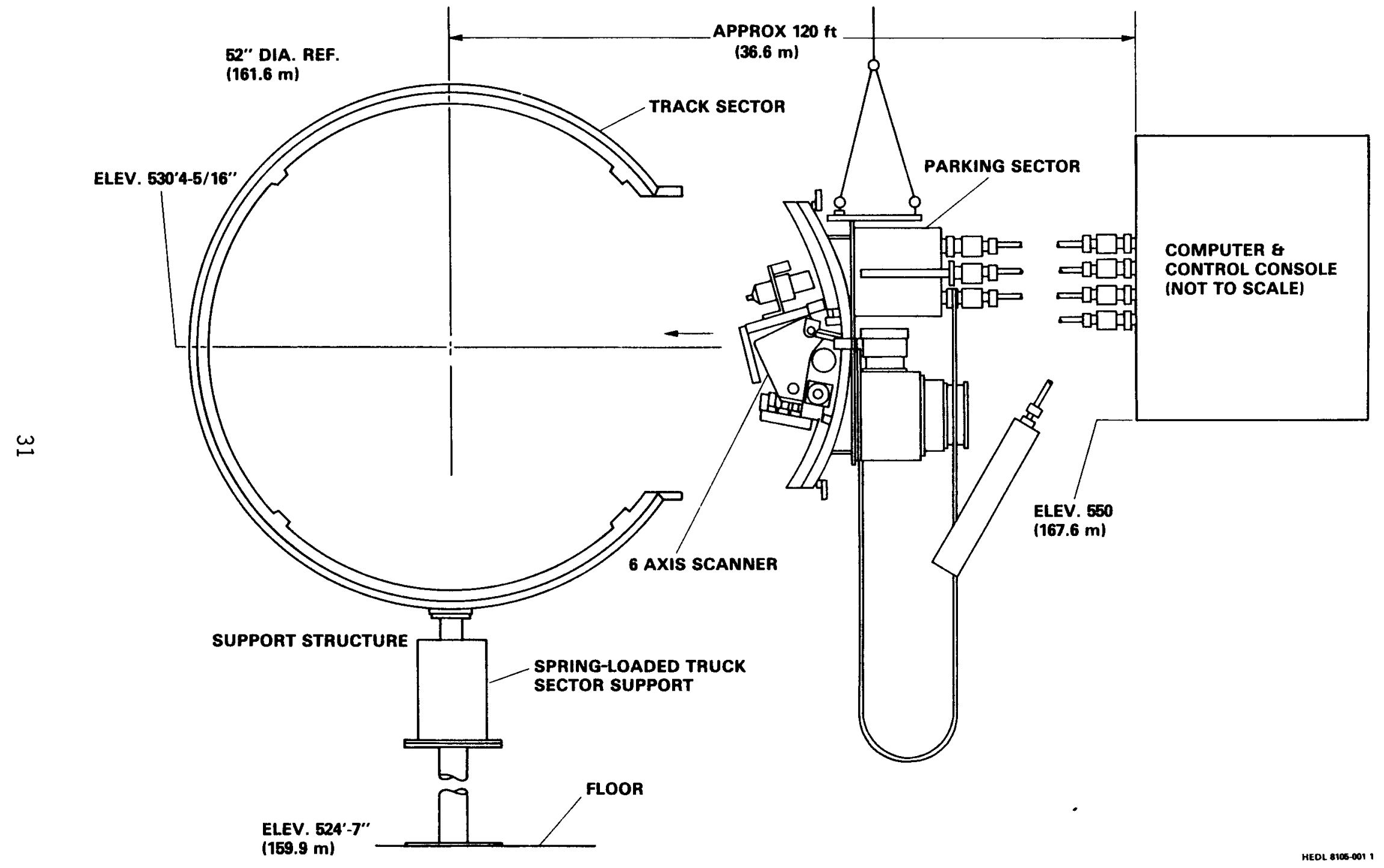

FIGURE 21. Ultrasonic Scanning Mechanism Track and Sector. 


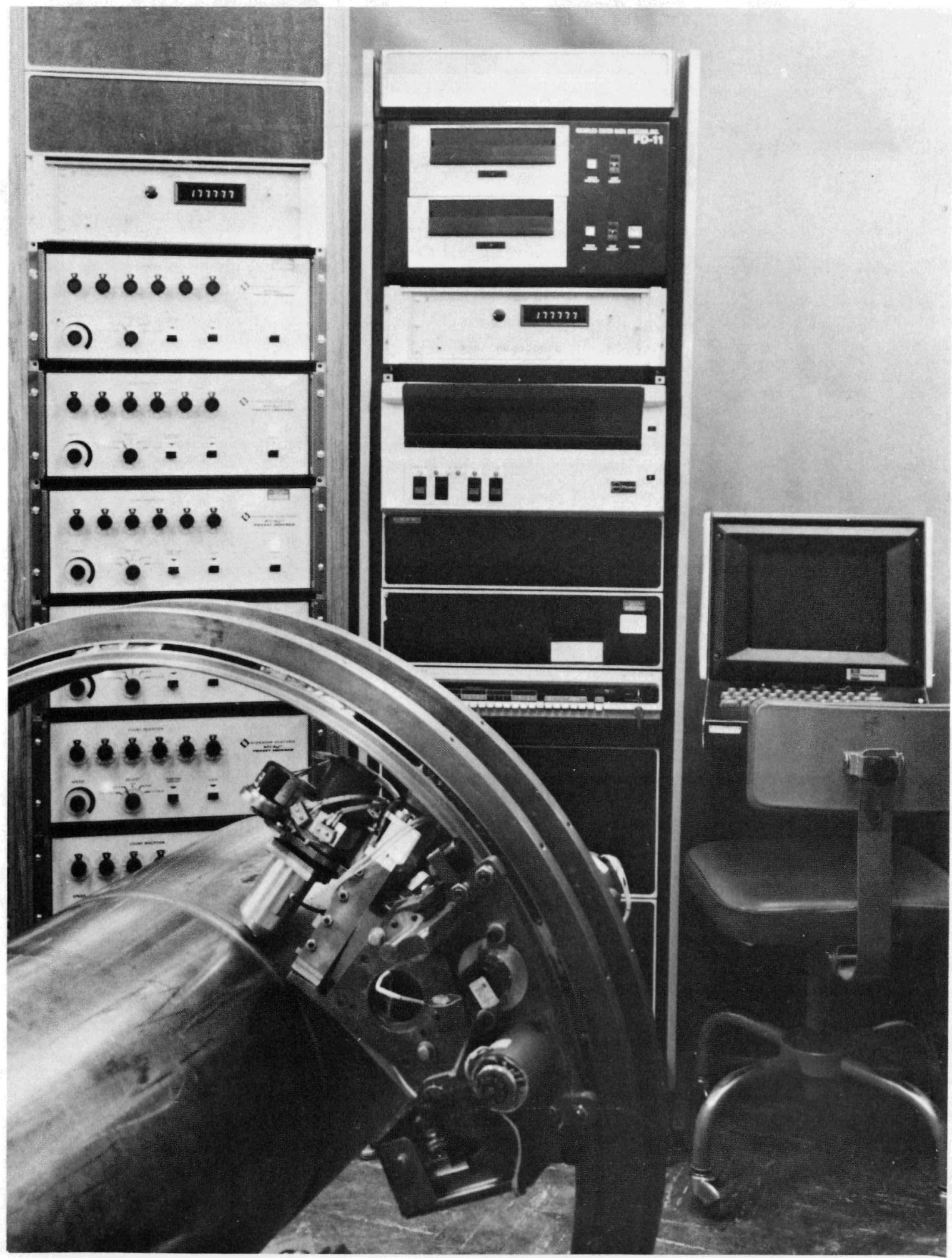

FIGURE 22. UTtrasonic Scanner. Neg 7903245-2cn 